\title{
PHYSICOCHEMICAL, PASTING, AND RHEOLOGICAL PROPERTIES OF PEARL MILLET STARCHES FROM DIFFERENT CULTIVARS AND THEIR RELATIONS
}

\author{
A.K. Siroha ${ }^{a *}$, S. Punia ${ }^{a}$, K.S. SANDhU ${ }^{a, b}$ and B.L. KarWASRA ${ }^{a}$ \\ ${ }^{a}$ Department of Food Science and Technology, Chaudhary Devi Lal University, Sirsa. India \\ ${ }^{\mathrm{b}}$ Department of Food Science and Technology, Maharaja Ranjit Singh Punjab Technical University, Bathinda. \\ India
}

(Received: 9 May 2019; accepted: 1 September 2019)

\begin{abstract}
Physicochemical, pasting, and rheological properties of pearl millet starches were studied and correlations among these properties were calculated. Amylose content, swelling power, and solubility of starches varied from 11.57 to $21.93 \%, 11.11$ to $17.91 \mathrm{~g} \mathrm{~g}^{-1}$ and 12.20 to $15.20 \%$, respectively. Volume $\%$ of starch granule size less than $10 \mu \mathrm{m}$ varied from 36.23 to $48.34 \%$, and 12.16 to $18.75 \%$ for above $20 \mu \mathrm{m}$ size of granule. Peak viscosity of starches varied from 1291 to $1853 \mathrm{mPa} \cdot \mathrm{s}, \mathrm{cv}$. RHB-173 had the highest value. Frequency sweep measurement of starch pastes revealed higher magnitude of $\mathrm{G}^{\prime}$ as compared to $\mathrm{G}^{\prime \prime}$ with increase in $\omega$, indicating visco-elastic behaviour. Yield stress $\left(\sigma_{\mathrm{o}}\right)$, consistency index $(\mathrm{K})$, and flow behaviour index $(\mathrm{n})$ were observed as 40.73 to $115.72 \mathrm{~Pa}, 0.729$ to 3.998 $\mathrm{Pa} \cdot \mathrm{s}$, and 0.604 to 0.964 , respectively. Starch pastes from cultivars studied showed shear thinning behaviour.

Keywords: pearl millet starch, physicochemical, rheology, particle size
\end{abstract}

Pearl millet (Pennisetum glaucum) belongs to family Poaceae and is widely grown around the world for feed and fodder. It is a drought tolerant crop. India is leading producer of millets (10 280000 tons) followed by Niger (3 886079 tons) (FAO, 2018). Pearl millet has protein, fat, crude fibre, and carbohydrate content of 9.7 to $11.3,5.1$ to $7.2,2.9$ to 3.8 , and 69.6 to $72.5 \%$, respectively (SirOHA et al., 2016). Starch is the principal carbohydrate constituent of pearl millet grain, amounting to 62.8 to $70.5 \%$ for different Indian cultivars as reported by Suma and UrooJ (2015).

In cereals, starch is the major stored carbohydrate, and its applicability in the industries greatly depends on its physico-chemical and structural properties (VAN HUNG \& MORITA, 2005). Major factors influencing the physicochemical properties of starch are amylose content and particle size (ZHANG et al., 2016). BHAT and RiAR (2016) reported that shape and particle size indicated a considerable effect on the functional properties of starch due to variations in distributional pattern of starch granule. Rheology studies the flow and deformation of substances during food processing and handling.

Starch from conventional sources (corn, rice, and potato) is widely used in food and non-food industries, but availability of starches is decreasing day by day due to increasing demand from various industries. So, acquisition of starch from other sources is required to provide even better and also cost effective substitute for conventional starches. Pearl millet starch is characterized by many researchers (CHOI et al., 2004; Wu et al., 2014; SumA \& UrooJ, 2015; Sandhu \& Siroha, 2017). However, there is limited information on the

\footnotetext{
* To whom correspondence should be addressed.

E-mail: siroha01@gmail.com
} 
relationship between physicochemical, pasting, and rheological properties of pearl millet starches. Keeping this in view, the present study was conducted to establish relations among different properties of starch from pearl millet cultivars.

\section{Materials and methods}

Pearl millet cultivars (cv.) (GHB-538, GHB-558, GHB-719, GHB-744, and GHB-905) were procured from Pearl Millet Research Station, Jamnagar, Gujarat, India. Pearl millet cultivars (RHB-30, RHB-58, RHB-121, RHB-173, and RHB-177) were procured from Rajasthan Agricultural Research Institute, Jaipur, Rajasthan, India.

\subsection{Starch isolation}

Starch was isolated from pearl millet grains by following the method described by SANDHU and SiNGH (2005). About $500 \mathrm{~g}$ of clean, sound, and whole grains were added to 1.251 of distilled water containing sodium metabisulphite $(0.1 \mathrm{~g} / 100 \mathrm{~g})$. After steeping $20 \mathrm{~h}$ at $50{ }^{\circ} \mathrm{C}$, the steep water was drained off and grains were ground in laboratory grinder (Maxie Plus, New Delhi, India). The ground slurry was sieved and centrifuged (Remi, New Delhi, India) at $605 \mathrm{~g}$ for $10 \mathrm{~min}$. The starch was then collected and dried in an oven (NSW-143, New Delhi, India) at $45^{\circ} \mathrm{C}$ for $12 \mathrm{~h}$.

\subsection{Amylose content}

WiLLIAMS and co-workers' (1970) method was adopted for determining the amylose content of starches.

\subsection{Swelling power and solubility}

LEACH and co-workers' (1959) method was adopted for determining the swelling power and solubility of starches.

\subsection{Particle size analysis}

For the measurement of granule size distribution of starches from different pearl millet cultivars, particle size analyser (Microtrac model no. S3500; Microtrac Instruments Limited, USA) was used. Dried starch sample was directly added to the sample port to reach an obscuration to $\sim 40 \%$. The granule size distribution was expressed in terms of the volumes of equivalent spheres.

\subsection{Pasting properties}

The pasting properties of starches were determined using starch cell of Modular Compact Rheometer (Model-52, Anton Paar, Austria). Starch slurries (8\%, total weight $15 \mathrm{~g}$ ) were used for all measurements. Initially, starch slurry were held at $50{ }^{\circ} \mathrm{C}$ for 1 min and then heated from 50 to $95{ }^{\circ} \mathrm{C}$ at a heating rate of $6{ }^{\circ} \mathrm{C} \mathrm{min}-1$, held for $2.7 \mathrm{~min}$, cooled to $50{ }^{\circ} \mathrm{C}$ at the same rate, and again held at $50^{\circ} \mathrm{C}$ for 2 min. Peak viscosity (PV), trough viscosity (TV), breakdown (BV), setback (SV), final viscosity (FV), and pasting temperature (PT) were obtained from the pasting graph. 


\subsection{Rheological properties}

1.6.1. Dynamic properties. Rheological measurement was made for starches with a Modular Compact Rheometer (Model-52, Anton Paar, Austria) equipped with parallel plate system $(0.04 \mathrm{~m}$ diameter \& gap size $1 \mathrm{~mm})$. The strain and frequency were set at $2 \%$ and $10 \mathrm{rad} \mathrm{s}^{-1}$, respectively, for all determinations. Starch suspensions of $8 \%(\mathrm{w} / \mathrm{w})$ concentration were loaded onto the ram of the rheometer and samples were heated from 45 to $95^{\circ} \mathrm{C}$ at the rate of $2{ }^{\circ} \mathrm{C} \mathrm{min}^{-1}$. The dynamic rheological properties, such as storage modulus $\left(\mathrm{G}^{\prime}\right)$, loss modulus $\left(\mathrm{G}^{\prime \prime}\right)$, and loss factor $(\tan \delta$ ) were determined for starches from different cultivars. Breakdown in $\mathrm{G}^{\prime}\left(\right.$ Peak $\mathrm{G}^{\prime}$ - Value of $\mathrm{G}^{\prime}$ at $90^{\circ} \mathrm{C}$ ) and $\mathrm{TG}^{\prime}$ was calculated as temperature at peak $\mathrm{G}^{\prime}$.

For frequency sweep measurement, the starch slurry $(8 \%, \mathrm{w} / \mathrm{w})$ was prepared and manually stirred, then heated at $85^{\circ} \mathrm{C}$ in a water bath followed by 3 min stirring. The sample was allowed to cool at room temperature and then loaded on the ram of the rheometer. Frequency sweep tests from 0.1 to $100 \mathrm{rad} \mathrm{s}^{-1}$ were performed at $25^{\circ} \mathrm{C} . \mathrm{G}^{\prime}, \mathrm{G}^{\prime \prime}$, and $\tan \delta$ were derived at $25^{\circ} \mathrm{C}$.

1.6.2. Steady shear measurement. PARK and co-workers' (2004) method with slight modification was used for determining the steady shear properties of starches. The sample preparation method has been described in frequency sweep measurement method. The starch sample (8\%) was sheared continuously from 1 to $500 \mathrm{~s}^{-1}$. In order to describe the variation in the rheological properties of samples under steady shear, the Herschel-Bulkley model was fitted to the data:

$$
\sigma=\sigma_{\mathrm{o}}+\mathrm{K}(\gamma)^{\mathrm{n}}
$$

where $\sigma$ is the shear stress $(\mathrm{Pa}), \sigma_{\mathrm{o}}$ is the yield stress, $\gamma$ is the shear rate $\left(\mathrm{s}^{-1}\right), \mathrm{K}$ is the consistency index $\left(\mathrm{Pa} \cdot \mathrm{s}^{\mathrm{n}}\right), \mathrm{n}$ is the flow behaviour index (dimensionless).

\subsection{Statistical analysis}

The data reported in the tables were carried out in triplicate, and they were subjected to oneway analysis of variance (ANOVA) using Minitab Statistical Software version 15 (Minitab, Inc., State College, USA).

\section{Results and discussion}

\subsection{Physicochemical properties}

Pearl millet starch from different cultivars had moisture: $10.2-11.4 \%$, protein: $0.28-0.68 \%$, fat: $0.28-0.43 \%$, and ash: $0.24-0.45 \%$ contents, respectively. Isolated starch had low ash, fat, and protein contents, which reflects the purity of the starches. Physicochemical properties (amylose, swelling power, and solubility) of starches are reported in Table 1. Amylose content of starches ranged from 11.57 to $21.93 \%$, cv. RHB- 121 and cv. RHB-30 had the highest and the lowest values, respectively. Amylose content positively correlated with $\mathrm{G}^{\prime}(\mathrm{r}=0.716$, $\mathrm{P}<0.05)$ and $\mathrm{G}^{\prime \prime}(\mathrm{r}=0.645, \mathrm{P}<0.05)$ in the case of frequency sweep. It was reported that amylose content of starches was affected by botanical sources, harvest time, climatic conditions, and types of soil during cultivation. Swelling power and solubility of starches varied from 11.11 to $17.91 \mathrm{~g} \mathrm{~g}^{-1}$ and 12.20 to $15.20 \%$, respectively, the highest values were observed for cv. GHB-538 and cv. RHB-177. Swelling power positively correlated with $\mathrm{G}^{\prime}$ $(\mathrm{r}=0.651, \mathrm{P}<0.05)$ during frequency sweep test. SANDHU and SirOHA (2017) reported amylose 
content, swelling power, and solubility of 13.6 to $18.1 \%$; 14.1 to $17.9 \mathrm{~g} \mathrm{~g}^{-1}$; and 10.4 to $16.2 \%$, respectively, for pearl millet starches.

Table 1. Swelling power, solubility, and amylose content of starches from different pearl millet cultivars

\begin{tabular}{lccc}
\hline Cultivars & $\begin{array}{c}\text { Amylose content } \\
(\%)\end{array}$ & $\begin{array}{c}\text { Swelling power } \\
\left(\mathrm{g} \mathrm{g}^{-1}\right)\end{array}$ & $\begin{array}{c}\text { Solubility } \\
(\%)\end{array}$ \\
\hline RHB-30 & $11.57 \pm 0.5^{\mathrm{a}}$ & $14.88 \pm 0.6^{\mathrm{c}}$ & $13.12 \pm 0.2^{\mathrm{d}}$ \\
RHB-58 & $15.30 \pm 0.4^{\mathrm{b}}$ & $16.64 \pm 0.4^{\mathrm{e}}$ & $15.03 \pm 0.3^{\mathrm{g}}$ \\
RHB-121 & $21.93 \pm 0.4^{\mathrm{h}}$ & $17.09 \pm 0.4^{\mathrm{f}}$ & $13.60 \pm 0.2^{\mathrm{e}}$ \\
RHB-173 & $18.40 \pm 0.3^{\mathrm{g}}$ & $15.20 \pm 0.6^{\mathrm{d}}$ & $12.20 \pm 0.4^{\mathrm{a}}$ \\
RHB-177 & $17.82 \pm 0.6^{\mathrm{c}}$ & $17.13 \pm 0.5^{\mathrm{f}}$ & $15.20 \pm 0.5^{\mathrm{h}}$ \\
GHB-538 & $16.21 \pm 0.5^{\mathrm{d}}$ & $17.91 \pm 0.3^{\mathrm{g}}$ & $12.82 \pm 0.3^{\mathrm{c}}$ \\
GHB-558 & $16.28 \pm 0.5^{\mathrm{d}}$ & $14.26 \pm 0.4^{\mathrm{b}}$ & $12.81 \pm 0.3^{\mathrm{c}}$ \\
GHB-719 & $18.21 \pm 0.7^{\mathrm{f}}$ & $17.10 \pm 0.4^{\mathrm{f}}$ & $14.40 \pm 0.4^{\mathrm{f}}$ \\
GHB-744 & $18.24 \pm 0.3^{\mathrm{f}}$ & $14.88 \pm 0.3^{\mathrm{c}}$ & $12.69 \pm 0.2^{\mathrm{b}}$ \\
GHB-905 & $15.87 \pm 0.2^{\mathrm{c}}$ & $11.11 \pm 0.7^{\mathrm{a}}$ & $12.70 \pm 0.4^{\mathrm{b}}$ \\
\hline
\end{tabular}

Means followed by the same superscript letter within a column do not differ significantly $(\mathrm{P}<0.05)$.

Mean ( \pm standard deviation) of triplicate analyses

\subsection{Particle size}

Particle size distribution of pearl millet starches from different cultivars is reported in Table 2. All samples showed unimodal distribution of particle size. Volume $\%$ of starch granule less than $10 \mu \mathrm{m}$ varied from 36.23 to $48.34 \%$, between $10-20 \mu \mathrm{m}$ from 38.35 to $48.26 \%$, and 12.16 to $18.75 \%$ for more than $20 \mu \mathrm{m}$ of granule size. It was reported that waxy millet starches showed granule size from 5-10 $\mu \mathrm{m}$ and polygonal shape with round edges with some pores on the surface (CHOI et al., 2004). ANNOR and co-workers (2014) reported starch granule size varied 3.5-23 $\mu \mathrm{m}$ for pearl millet. SANDHU and SiROHA (2017) observed that SEM images of pearl millet starches showed variation in size and shape from small to large, spherical and polygonal. Physical and chemical properties of the starch granules, such as mean granule size, granule size distribution, amylose/amylopectin ratio, and mineral content affect the starch paste behaviour in aqueous systems (MADSEN \& CHRISTENSEN, 1996).

\subsection{Pasting properties}

Pasting properties provide important information about the cooking behaviour of starches during heating and cooking cycles (Fig. 1). As reported by RINCÓN-LONDONO and co-workers (2016), PV indicates hydrogel stability with characteristic morphology. PV tells about maximum swelling of starch granule, which depends upon size of granule. PV of starches varied from 1291 to $1853 \mathrm{mPa} \cdot \mathrm{s}$, the highest value was observed for cv. RHB-173, which may be due to more stable hydrogel as compared to other cultivars. BV of starches ranged from 146 to $518 \mathrm{mPa} \cdot \mathrm{s}, \mathrm{cv}$. RHB-177 had the lowest value. SV of starches ranged between 506 to $961 \mathrm{mPa} \cdot \mathrm{s}$, the highest and the lowest values were observed for cv. RHB-30 and cv. 
GHB-744, respectively. PT of starches varied from 74.0 to $85.4{ }^{\circ} \mathrm{C}$, cv. RHB-30 had the highest value. SANDHU and co-workers (2018) observed PV, BV, SV, and PT for pearl millet starch as $1068,506,351 \mathrm{cP}$, and $81.2{ }^{\circ} \mathrm{C}$, respectively. Relationship between pasting parameters were also evaluated. PV positively correlated with $\mathrm{BV}(\mathrm{r}=0.903, \mathrm{P}<0.01)$, $\mathrm{TV}(\mathrm{r}=0.854, \mathrm{P}<0.01)$, SV $(\mathrm{r}=0.761, \mathrm{P}<0.05)$, and $\mathrm{FV}(\mathrm{r}=0.922, \mathrm{P}<0.01)$. BV positively correlated with SV $(\mathrm{r}=0.829, \mathrm{P}<0.01)$ and FV $(\mathrm{r}=0.828, \mathrm{P}<0.01)$. TV was found positively correlated with FV $(\mathrm{r}=0.794, \mathrm{P}<0.01)$. SV positively correlated with $\mathrm{FV}(\mathrm{r}=0.913, \mathrm{P}<0.01)$. PT was found positively correlated with $\mathrm{G}^{\prime \prime}(\mathrm{r}=0.651, \mathrm{P}<0.05)$ during heating profile.

Table 2. Particle size distribution of starches from different pearl millet cultivars

\begin{tabular}{lccc}
\hline Cultivars & \multicolumn{1}{c}{ Size $(\mu \mathrm{m})$} & $>20$ \\
\cline { 2 - 4 } & \multicolumn{1}{c}{$\begin{array}{c}10-20 \\
(\% \text { Volume })\end{array}$} & $12.61 \pm 0.06^{\mathrm{b}}$ \\
\hline RHB-30 & $39.12 \pm 0.10^{\mathrm{c}}$ & $48.26 \pm 0.21^{\mathrm{h}}$ & $13.13 \pm 0.05^{\mathrm{c}}$ \\
RHB-58 & $44.67 \pm 0.16^{\mathrm{h}}$ & $42.20 \pm 0.16^{\mathrm{c}}$ & $17.93 \pm 0.03^{\mathrm{g}}$ \\
RHB-121 & $40.75 \pm 0.08^{\mathrm{e}}$ & $41.30 \pm 0.20^{\mathrm{b}}$ & $18.29 \pm 0.03^{\mathrm{h}}$ \\
RHB-173 & $39.55 \pm 0.15^{\mathrm{d}}$ & $42.15 \pm 0.26^{\mathrm{c}}$ & $16.32 \pm 0.05^{\mathrm{e}}$ \\
RHB-177 & $41.44 \pm 0.11^{\mathrm{f}}$ & $42.26 \pm 0.22^{\mathrm{c}}$ & $16.34 \pm 0.04^{\mathrm{e}}$ \\
GHB-538 & $36.64 \pm 0.10^{\mathrm{b}}$ & $47.04 \pm 0.21^{\mathrm{g}}$ & $13.30 \pm 0.06^{\mathrm{d}}$ \\
GHB-558 & $48.34 \pm 0.15^{\mathrm{i}}$ & $38.35 \pm 0.25^{\mathrm{a}}$ & $16.79 \pm 0.05^{\mathrm{f}}$ \\
GHB-719 & $40.64 \pm 0.11^{\mathrm{e}}$ & $42.57 \pm 0.22^{\mathrm{d}}$ & $18.75 \pm 0.06^{\mathrm{i}}$ \\
GHB-744 & $36.23 \pm 0.19^{\mathrm{a}}$ & $45.04 \pm 0.16^{\mathrm{f}}$ & $12.16 \pm 0.06^{\mathrm{a}}$ \\
GHB-905 & $43.59 \pm 0.20^{\mathrm{g}}$ & $44.27 \pm 0.12^{\mathrm{e}}$ & \\
\hline
\end{tabular}

Means followed by the same superscript letter within a column do not differ significantly $(\mathrm{P}<0.05)$.

Mean ( \pm standard deviation) of triplicate analyses

\subsection{Rheological properties}

2.4.1. Dynamic shear properties. Significant $(\mathrm{P}<0.05)$ differences were observed for rheological properties of starch suspensions during heating (Table 3). The amount of energy stored in material and recovered from it per cycle is called as $\mathrm{G}^{\prime}$, while the amount of energy dissipated or lost per cycle of sinusoidal deformation is described as $\mathrm{G}^{\prime \prime}$. For all starches, $\mathrm{G}^{\prime}$ and $\mathrm{G}^{\prime \prime}$ increased progressively during heating followed by a drop, and varied from 361 to $922 \mathrm{~Pa}$ and 62.4 to $89.9 \mathrm{~Pa}$. The highest values for cv. RHB-121 and cv. RHB-177, while the lowest values were being observed for $\mathrm{cv}$. GHB-905. Before TG' reached maximum, both $\mathrm{G}^{\prime}$ and $\mathrm{G}^{\prime \prime}$ increased, which may be attributed to swelling of granules of starch and leaching of chains of amylose, contributing to the formation of a composite network of solved materials supporting partially disintegrated starch granules (AROcAs et al., 2009). The variations in starch granular structure may be responsible for the distinction in $\mathrm{G}^{\prime}, \mathrm{G}^{\prime \prime}$, and tan $\delta$ during the heating cycle of these starches from different cultivars (SVEGMARK \& HERMANSSON, 1993). $\tan \delta\left(\mathrm{G}^{\prime \prime} / \mathrm{G}^{\prime}\right)$ values of starches were observed less than 1 , which shows their elastic behaviour. Breakdown in $\mathrm{G}^{\prime}$ (difference between peak $\mathrm{G}^{\prime}$ and value $\mathrm{G}^{\prime}$ at $90^{\circ} \mathrm{C}$ ) value varied from 24 to $444 \mathrm{~Pa}, \mathrm{cv}$. RHB-121 had the highest value. 

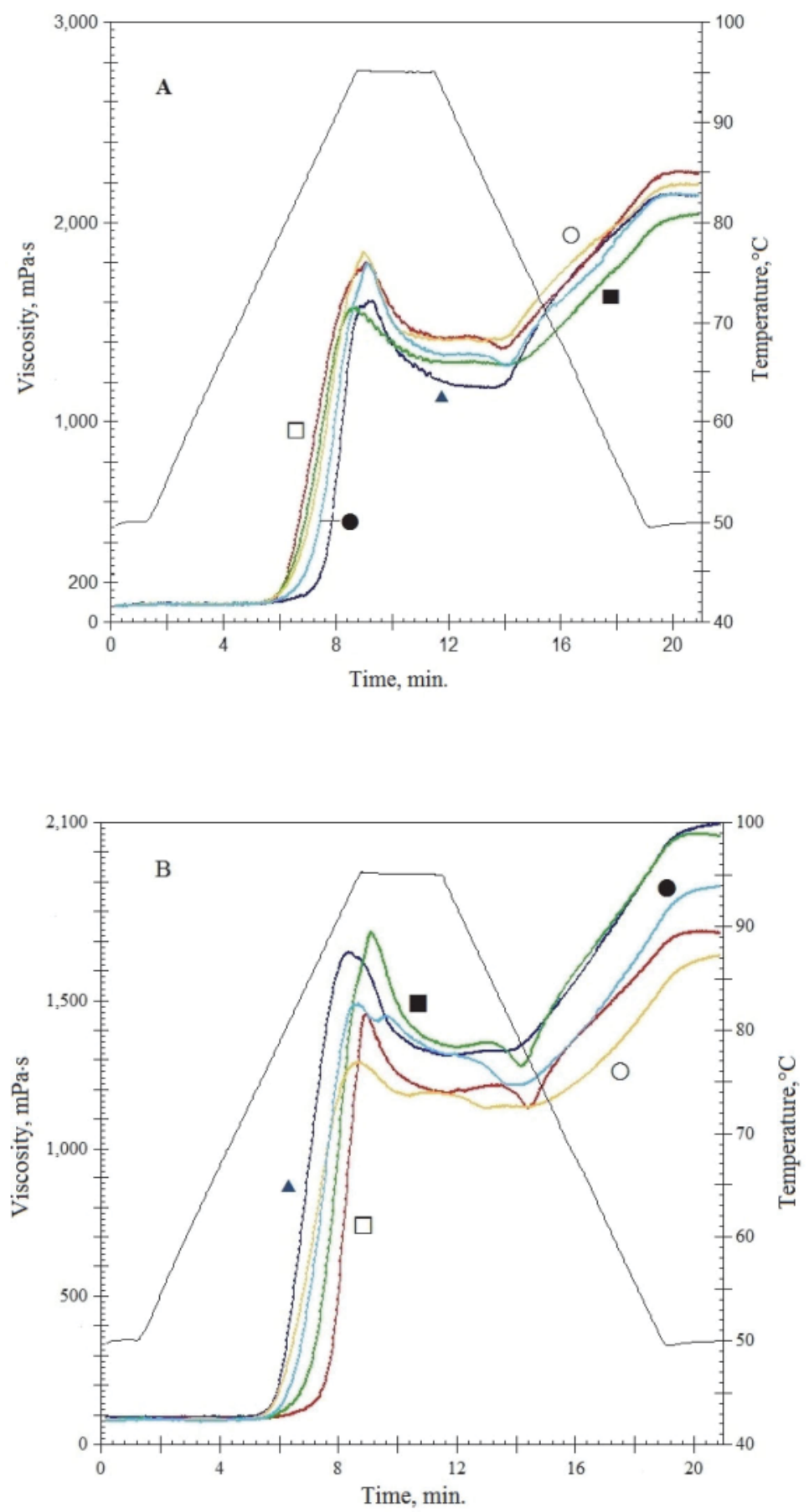

Fig. $1 \mathrm{~A}, \mathrm{~B}$ ): Pasting properties of starches from different pearl millet cultivars

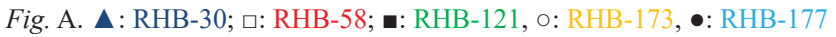

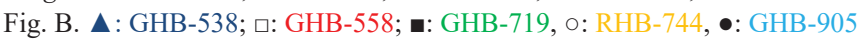
Acta Alimentaria 49, 2020 
Table 3. Rheological properties of starches from different pearl millet cultivars during heating

\begin{tabular}{llllll}
\hline Cultivars & $\mathrm{G}^{\prime}(\mathrm{Pa})$ & $\mathrm{G}^{\prime \prime}(\mathrm{Pa})$ & $\begin{array}{c}\text { Breakdown in } \\
\mathrm{G}^{\prime}(\mathrm{Pa})\end{array}$ & Tan $\delta$ & $\mathrm{TG}^{\prime}\left({ }^{\circ} \mathrm{C}\right)$ \\
\hline RHB-30 & $844 \pm 11^{\mathrm{i}}$ & $88.8 \pm 08^{\mathrm{g}}$ & $149 \pm 06^{\mathrm{d}}$ & $0.10^{\mathrm{a}}$ & $82.59 \pm 0.2^{\mathrm{c}}$ \\
RHB-58 & $447 \pm 07^{\mathrm{c}}$ & $73.5 \pm 05^{\mathrm{c}}$ & $27 \pm 02^{\mathrm{a}}$ & $0.16^{\mathrm{b}}$ & $87.59 \pm 0.3^{\mathrm{e}}$ \\
RHB-121 & $922 \pm 13^{\mathrm{j}}$ & $72.5 \pm 07^{\mathrm{b}}$ & $444 \pm 09^{\mathrm{g}}$ & $0.07^{\mathrm{a}}$ & $75.08 \pm 0.3^{\mathrm{a}}$ \\
RHB-173 & $403 \pm 10^{\mathrm{b}}$ & $73.6 \pm 05^{\mathrm{c}}$ & 0 & $0.18^{\mathrm{b}}$ & $90.08 \pm 0.5^{\mathrm{f}}$ \\
RHB-177 & $635 \pm 11^{\mathrm{f}}$ & $89.9 \pm 07^{\mathrm{h}}$ & $80 \pm 4^{\mathrm{b}}$ & $0.14^{\mathrm{b}}$ & $85.09 \pm 0.2^{\mathrm{d}}$ \\
GHB-538 & $827 \pm 16^{\mathrm{h}}$ & $72.5 \pm 05^{\mathrm{b}}$ & $305 \pm 09^{\mathrm{f}}$ & $0.08^{\mathrm{a}}$ & $75.08 \pm 0.2^{\mathrm{a}}$ \\
GHB-558 & $554 \pm 14^{\mathrm{d}}$ & $77.9 \pm 05^{\mathrm{d}}$ & 0 & $0.14^{\mathrm{b}}$ & $90.07 \pm 0.4^{\mathrm{f}}$ \\
GHB-719 & $713 \pm 09^{\mathrm{g}}$ & $84.8 \pm 07^{\mathrm{f}}$ & $240 \pm 06^{\mathrm{e}}$ & $0.11^{\mathrm{a}}$ & $77.59 \pm 0.2^{\mathrm{b}}$ \\
GHB-744 & $609 \pm 11^{\mathrm{e}}$ & $78.8 \pm 03^{\mathrm{e}}$ & $119 \pm 07^{\mathrm{c}}$ & $0.12^{\mathrm{a}}$ & $85.08 \pm 0.3^{\mathrm{d}}$ \\
GHB-905 & $361 \pm 08^{\mathrm{a}}$ & $62.4 \pm 04^{\mathrm{a}}$ & $24 \pm 02^{\mathrm{a}}$ & $0.17^{\mathrm{b}}$ & $87.58 \pm 0.3^{\mathrm{e}}$ \\
\hline
\end{tabular}

Means followed by the same superscript letter within a column do not differ significantly $(\mathrm{P}<0.05)$.

Mean ( \pm standard deviation) of triplicate analyses

$\mathrm{G}^{\prime}$ : storage modulus; $\mathrm{G}^{\prime \prime}$ : loss modulus, tan $\delta$ : loss factor, $\mathrm{TG}^{\prime}$ : the temperature at which $\mathrm{G}^{\prime}$ is maximal

Dynamic rheological properties of pearl millet starches during frequency sweep are shown in Figure 2A, B. The magnitude of $G^{\prime}$ and $G^{\prime \prime}$ values during frequency sweep varied from 788 to $1509 \mathrm{~Pa}$ and from 66.4 to $96.5 \mathrm{~Pa}$, respectively; the highest value was observed for cv. GHB-719. SANDHU and SiroHA (2017) reported that magnitudes of $G^{\prime}$ and $G^{\prime \prime}$ during frequency sweep test were 997 to $1871 \mathrm{~Pa}$ and 67 to $107 \mathrm{~Pa}$, respectively, for pastes of starch from different cultivars. No cross over was observed between $\mathrm{G}^{\prime}$ and $\mathrm{G}^{\prime \prime}$, showing the stability of starch pastes over the observed frequency range $\left(0.1-100 \mathrm{rad} \mathrm{s}^{-1}\right)$. $\mathrm{G}^{\prime}$ value was found higher than $\mathrm{G}^{\prime \prime}$ value, which shows that the starch paste was more elastic than viscous. Tan $\delta$ value of starch pastes varied from 0.06 to 0.08 , indicating that all samples were more elastic than viscous. $\mathrm{G}^{\prime}$ was found positively correlated with $\mathrm{G}^{\prime \prime}(\mathrm{r}=0.938, \mathrm{P}<0.01)$ during frequency sweep test. $\mathrm{G}^{\prime}$ was positively correlated with granule size of starch $(>20 \mu \mathrm{m})(\mathrm{r}=0.759$, $\mathrm{P}<0.05) . \mathrm{G}^{\prime \prime}$ was also found positively correlated with granule size of starch $(>20 \mu \mathrm{m})$ $(\mathrm{r}=0.696, \mathrm{P}<0.05)$.

2.4.2. Steady shear properties. The experimental data obtained from steady shear profile for starch pastes was analysed by Herschel-Bulkley model, and $\sigma_{0}$, n, and $\mathrm{K}$ were studied (Table 4). Correlation coefficient square $\left(\mathrm{R}^{2}\right)$ was observed from 0.969 to $0.996 . \mathrm{n}$ of starch pastes ranged from 0.604 to 0.964 , indicating the shear thinning behaviour of starch. Normally $\mathrm{n}$ value is used to describe fluid and semi-fluid behaviour, with $\mathrm{n}$ value of less than 1 describing a shear thinning, while $\mathrm{n}$ value greater than 1 showing a shear thickening fluid behaviour. Minimum force required starting flow of starch paste is called $\sigma_{o}$, it varied from 40.73 to 115.72 $\mathrm{Pa}$, the highest and the lowest values were observed for cv. GHB-744 and GHB-558, respectively. $\mathrm{K}$ value of starches ranged from 0.729 to $3.998 \mathrm{~Pa} \cdot \mathrm{s}$, cv. GHB-558 had the highest value. SANDHU and SIROHA (2017) reported K value for starch pastes from 1.69 to 54.5 Pa.s for different pearl millet cultivars. $\sigma_{\mathrm{o}}$ was found negatively correlated with $\mathrm{K}$ $(\mathrm{r}=0.671, \mathrm{P}<0.05)$. $\sigma 0$ also negatively correlated with granule size of starch $(<10 \mu \mathrm{m})$ $(\mathrm{r}=0.715, \mathrm{P}<0.05)$. 

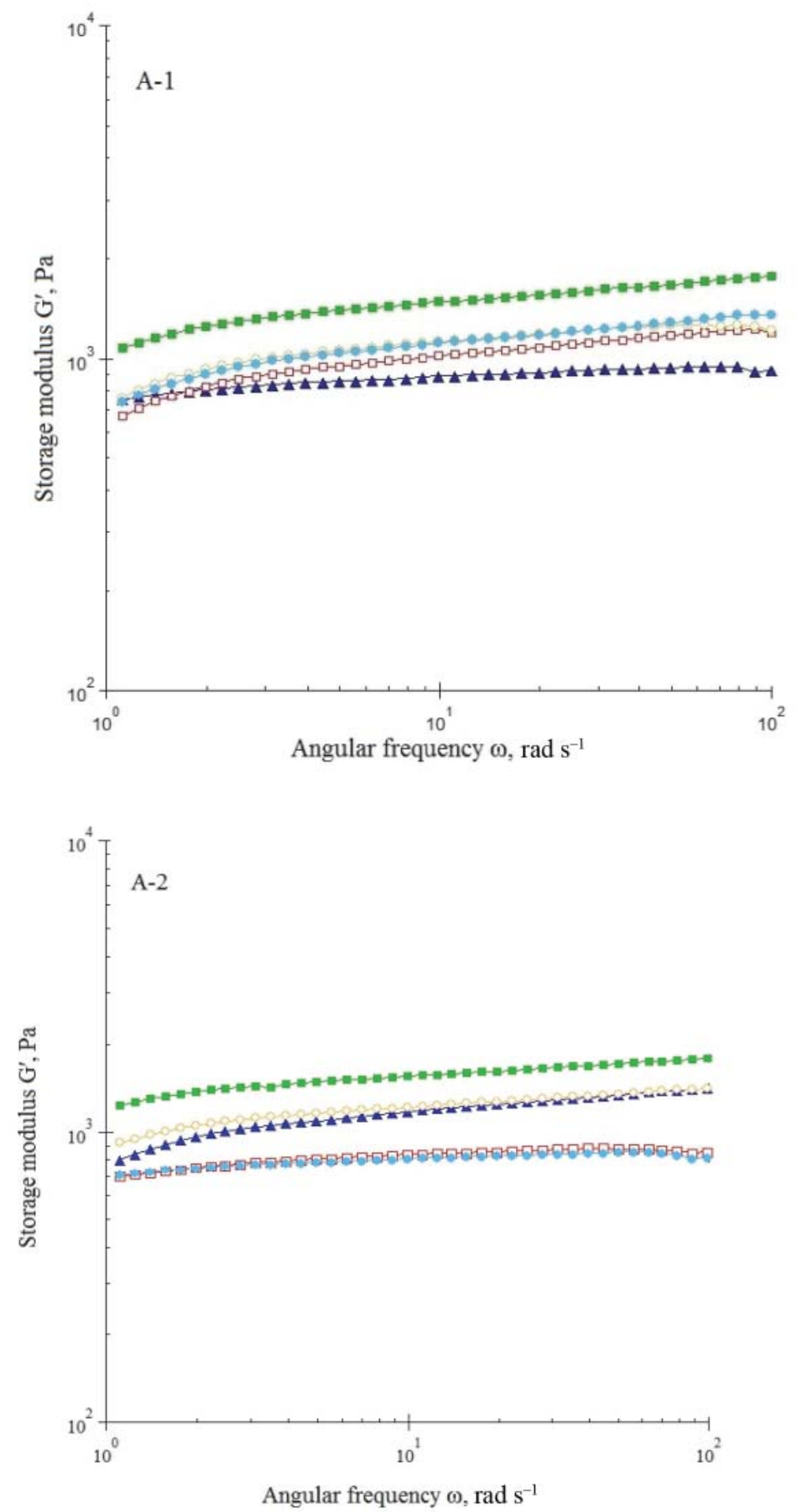

Fig. 2 (A-1, A-2): Angular frequency dependence of $\mathrm{G}^{\prime}$ at $25^{\circ} \mathrm{C}$ for starches from different pearl millet cultivars; (B-1, B-2) Angular frequency dependence of $\mathrm{G}^{\prime \prime}$ at $25^{\circ} \mathrm{C}$ for starches from different pearl millet cultivars Fig. 2A-1, B-1. $\boldsymbol{\Lambda}$ : RHB-30; 口: RHB-58; $\mathbf{~ : ~ R H B - 1 2 1 , ~ o : ~ R H B - 1 7 3 , ~ \bullet : ~ R H B - 1 7 7 ~}$ Fig. 2A-2, B-2. $\boldsymbol{\Delta}$ : GHB-538; 口: GHB-558; п: GHB-719, o: RHB-744, •: GHB-905 

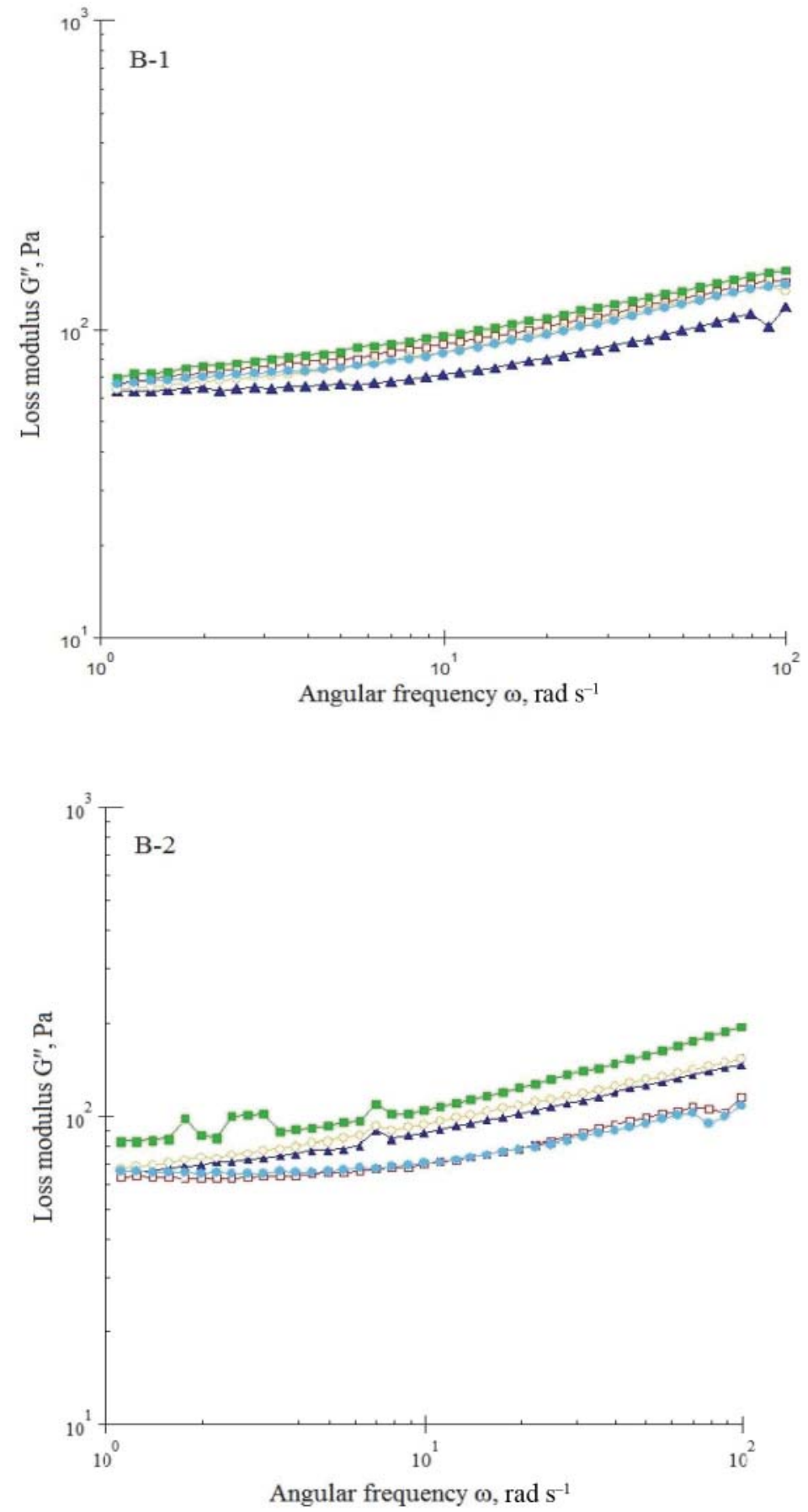

Fig. 2. continued 
Table 4. Herschel-Bulkey model fitted to flow curve of starch pastes from different pearl millet cultivars during steady shear rate

\begin{tabular}{|c|c|c|c|c|}
\hline Cultivars & Yield stress $\sigma_{\mathrm{o}}(\mathrm{Pa})$ & $\begin{array}{c}\text { Consistency index } \\
\mathrm{K}(\mathrm{Pa} \cdot \mathrm{s})\end{array}$ & $\mathrm{n}$ & $\mathrm{R}^{2}$ \\
\hline RHB-30 & $84.45 \pm 2.76^{\mathrm{g}}$ & $0.729 \pm 0.03^{\mathrm{a}}$ & $0.960 \pm 0.008^{\mathrm{d}}$ & $0.989^{\mathrm{a}}$ \\
\hline RHB-58 & $80.12 \pm 2.17^{\mathrm{e}}$ & $2.434 \pm 0.14^{\mathrm{g}}$ & $0.783 \pm 0.006^{\mathrm{b}}$ & $0.989^{\mathrm{a}}$ \\
\hline RHB-121 & $102.83 \pm 1.90^{\mathrm{i}}$ & $0.733 \pm 0.01^{\mathrm{a}}$ & $0.964 \pm 0.005^{\mathrm{d}}$ & $0.969^{\mathrm{a}}$ \\
\hline RHB-173 & $72.02 \pm 1.80^{\mathrm{d}}$ & $2.645 \pm 0.14^{\mathrm{h}}$ & $0.739 \pm 0.008^{\mathrm{b}}$ & $0.989^{\mathrm{a}}$ \\
\hline RHB-177 & $70.54 \pm 1.12^{\mathrm{c}}$ & $1.893 \pm 0.03^{\mathrm{d}}$ & $0.773 \pm 0.008^{\mathrm{b}}$ & $0.989^{\mathrm{a}}$ \\
\hline GHB-538 & $90.86 \pm 2.45^{\mathrm{h}}$ & $1.002 \pm 0.02^{\mathrm{b}}$ & $0.907 \pm 0.005^{\mathrm{d}}$ & $0.985^{\mathrm{a}}$ \\
\hline GHB-558 & $40.73 \pm 1.22^{\mathrm{a}}$ & $3.998 \pm 0.05^{\mathrm{i}}$ & $0.604 \pm 0.006^{\mathrm{a}}$ & $0.992^{\mathrm{a}}$ \\
\hline GHB-719 & $62.76 \pm 2.22^{\mathrm{b}}$ & $2.141 \pm 0.14^{\mathrm{f}}$ & $0.750 \pm 0.005^{b}$ & $0.985^{\mathrm{a}}$ \\
\hline GHB-744 & $115.72 \pm 2.16^{\mathrm{j}}$ & $2.128 \pm 0.15^{\mathrm{e}}$ & $0.870 \pm 0.004^{\mathrm{c}}$ & $0.996^{\mathrm{a}}$ \\
\hline GHB-905 & $84.11 \pm 1.75^{\mathrm{f}}$ & $1.303 \pm 0.04^{\mathrm{c}}$ & $0.859 \pm 0.008^{\mathrm{c}}$ & $0.982^{\mathrm{a}}$ \\
\hline
\end{tabular}

Mean ( \pm standard deviation) of triplicate analyses. Means followed by the same superscript letter within a column do not differ significantly $(\mathrm{P}<0.05)$; n: flow behaviour index

\section{Conclusions}

The isolated starches from different pearl millet cultivars showed significant $(\mathrm{P}<0.05)$ differences in the properties showing their suitability for diverse applications. This investigation improves the chances of pearl millet starch to be utilized as a starch source in food and non-food industries, which mainly depend on rice, corn, and potato starch. Understanding rheological properties are important in predicting the behaviour of starch when used in food products and movement of starch pastes in pipelines and pumps in starch industries. All starches showed more elastic behaviour than viscous. Significant correlations among the properties of different starches were observed. All starch pastes showed shear thinning behaviour, a typical characteristic of pseudoplastic fluids. Further research may be carried out on utilization of pearl millet starch in various food applications and on modification of starches with various physical, chemical, and enzymatic methods.

\section{References}

Annor, G.A., Marcone, M., Bertoft, E. \& Seetharaman, K. (2014): Physical and molecular characterization of millet starches. Cereal Chem., 91, 286-292.

Arocas, A., Sanz, T. \& Fiszman, S.M. (2009): Influence of corn starch type on the rheological properties of a white sauce after heating and freezing. Food Hydrocolloids, 23, 901-907.

BHAT, F.M. \& RiAR, C.S. (2016): Effect of amylose, particle size \& morphology on the functionality of starches of traditional rice cultivars. Int. J. Biol. Macromol., 92, 637-644.

Choi, H., KIm, W. \& Shin, M. (2004): Properties of Korean amaranth starch compared to waxy millet and waxy sorghum starches. Starch/Stärke, 56, 469-477.

FAO (2018): The statistical division. http://www.fao.org/faostat/en/\#data/QC (last accessed 19 October 2018).

LeACH, H.W., McCowen, L.D. \& SCHOCH, T.J. (1959): Structure of the starch granule I. Swelling and solubility patterns of various starches. Cereal Chem., 36, 534-544. 
Madsen, M.H. \& Christensen, D.H. (1996): Changes in viscosity properties of potato starch during growth. Starch/ Stärke, 48, 245-249.

Park, S., Chung, M. \& Yoo, B. (2004): Effect of octenyl succinylation on rheological properties of corn starch pastes. Starch/Stärke, 56, 399-406.

Rincón-Londono, N., Millan-Malo, B. \& Rodríguez-Garcia, M.E. (2016): Analysis of thermal pasting profile in corn starch rich in amylose and amylopectin: Physicochemical transformations, part II. Int. J. Biol. Macromol., 89, 43-53.

SandHu, K.S. \& Singh, N. (2005): Relationships between selected properties of starches from different corn lines. Int. J. Food Prop., 8, 481-491.

SAndHU, K.S. \& Siroha, A.K. (2017): Relationships between physicochemical, thermal, rheological and in vitro digestibility properties of starches from pearl millet cultivars. LWT-Food Sci. Technol., 83, 213-224.

Sandhu, K.S., Siroha, A.K., Kaur, M. \& Punia, S. (2018): Pearl millet: Flour and starch properties, -in: Sharma, H.K. \& PAnesar, P.S. (Eds): Technologies in food processing, Apple Academic Press Inc.,USA, pp. 289-314.

Siroha, A.K., SAndHu, K.S. \& KaUR, M. (2016): Physicochemical, functional and antioxidant properties of flour from pearl millet varieties grown in India. J. Food Meas. Charact., 10(2), 311-318.

Suma, P.F. \& Urooj, A. (2015): Isolation and characterization of starch from pearl millet (Pennisetum typhoidium) flours. Int. J. Food Prop., 18, 2675-2687.

Svegmark, K. \& Hermansson, A.M. (1993): Microstructure and rheological properties of composites of potato starch granules and amylose: a comparison of observed and predicted structure. Food Struct., 12, 181-193.

VAn Hung, P. \& Morita, N. (2005): Effect of granule sizes on physicochemical properties of cross-linked and acetylated wheat starches. Starch/Stärke, 57, 413-420.

Williams, P. C., Kuzina, F. D. \& Hlynka, L. (1970): A rapid calorimetric procedure for estimating the amylose content of starches and flour. Cereal Chem., 47, 411-421.

Wu, Y., Lin, Q., CuI, T. \& XIAO, H. (2014): Structural and physical properties of starches isolated from six varieties of millet grown in China. Int. J. Food Prop., 17, 2344-2360.

Zhang, Y., ZhU, K., He, S., TAN, L. \& KonG, X. (2016): Characterizations of high purity starches isolated from five different jackfruit cultivars. Food Hydrocolloids, 52, 785-794. 